\title{
Reproduction of Daphnia pulex in a Northern Italy pond
}

\author{
Valeria ROSSI, ${ }^{*}$ Catia MAURONE, Giorgio BENASSI, Ireneo FERRARI \\ University of Parma, Department of Life Sciences, Viale Usberti, 11/A Parma, Italy \\ *Corresponding author: valeria.rossi@unipr.it
}

\begin{abstract}
This paper reports on the occurrence of Daphnia pulex in a small fishless water body of Northern Italy (Bodrio del pastore III) and describes its population dynamics. Bodrio is a typical water body originated by erosion from the old Po river-bed surface. During a three year study (2011-2013), D. pulex population showed an increase in density from spring to early summer, it declined in July-August and did not recover, presumably from ephippia, until the following spring. The seasonal dynamics was related to the species thermal tolerance and to invertebrate predation by Chaoborus that resulted in juvenile high mortality and in adaptive predator-avoidance cyclomorphosis. Seasonal variation was observed in the frequency of individuals, most juveniles, showing neckteeth. D. pulex population reproduces by cyclical parthenogenesis and showed a very early investment in sexual reproduction, independent of population density. Males and ephippial females appeared at the beginning of growth season before the density peak according to a typical feature of Daphnia populations from temporary habitats. This suggests a lower influence of the environmental factors on sex determination compared to populations inhabiting more permanent habitats. Lineages that produce males and ephippial females early in the season had lower growth rate than parthenogenetic ones but may preserve from selection pressure by predators a significant percentage of genetic variation linked to sex allocation so that evolution proceeds toward earlier and increased sexual reproduction. Our results suggest further investigation to verify whether the current population is the last remnant of a once much larger metapopulation eventually reduced by anthropogenic disturbances or if it represents the invasion of North American strains.
\end{abstract}

Key words: Invertebrate predation, cyclomorphosis, cyclical parthenogenesis, sex allocation, recruitment from ephippia.

Received: February 2014. Accepted: April 2014.

\section{INTRODUCTION}

Daphnia pulex Leydig, 1860 is a complex of species studied by limnologists for over a century and no group of freshwater zooplankton has been more intensively studied (Kerfoot, 1980; Peters and de Bernardi, 1987; Colbourne and Hebert, 1996; Seda and Petrusek, 2011).

D. pulex is globally distributed throughout the temperate zone and inhabits remarkably different types of lentic habitats (Colbourne et al., 1998). It plays pivotal roles in aquatic food webs, serving as primary grazers of algae, bacteria, and protozoans, and as primary forage for fish (Tessier et al., 2001). It is an important model organism in (developmental) phenotypic plasticity that involves a vast number of traits (e.g., size, morphology, aging, behaviour) and can be induced by a variety of environmental cues (e.g., temperature, predator kairomones, toxins) (Parejko and Dodson, 1991; Spitze, 1992; Weider and Pijanowska, 1993). In the most recent developments of environmental genomics, the complete sequence of its genome will provide an exceptionally powerful tool for addressing fundamental issues in ecology, ecotoxicology, and evolution and in understanding genome-environment interactions (Eads et al., 2008; Schaack, 2008; Colbourne et al., 2011).

Most studies of D. pulex have focused on North Amer- ican populations because of its dominance in freshwater habitats. D. pulex propensity for hybridization and its variation in reproductive mode provided an excellent opportunity to explore breeding system diversity and ploidy levels along geographical gradients (Adamowicz et al., 2002; Jose and Dufresne, 2009; Vergilino et al., 2011). Temperate populations reproduce by cyclical parthenogenesis when one or more parthenogenetic (asexual) generations alternate with a sexual generation, generally cued by factors that are indicative of environmental deterioration (i.e. low food level, crowding, changes in temperature and photoperiod) (Stross, 1987; Koch et al., 2009). Some (asexual) lineages have made permanent transitions to obligate parthenogenesis, some asexual lineages are polyploid and are prevalent in arctic and in some high alpine areas whereas diploid lineages dominate in temperate zones (Innes and Hebert, 1988; Weider et al., 1999; Hebert and Finston, 2001; Adamowicz et al., 2002; Weider and Hobaek, 2003; Aguilera et al., 2007; Mergeay et al., 2008). In North America, eastern populations are strictly asexuals, mixed populations (both sexuals and asexuals) are found in Ontario, whereas western populations reproduce by cyclical parthenogenesis (Beaton and Hebert, 1988). The ecological differentiation of clonal lineages suggested that they have diverged physiologically 
into ecotypes as a result of local adaptations (Weider and Hebert, 1987; Dufresne and Hebert, 1998).

The identity of European and American populations of morphologically similar species may be doubtful (Hrbacek, 1987). The accumulation of genetic data has showed that North American and European D. pulex are genetically two distinct species and nomenclature of the D. pulex complex is not resolved (Colbourne et al., 1998; Palsoon, 2000; Mergeay et al., 2006; Petrusek et al., 2008; Crease et al., 2012; Markova et al., 2013). Even in Europe, asexual strains of $D$. pulex show a more northerly distribution than sexual ones (Ward et al., 1994; Weider and Hobaek, 1997) and both lineages may co-exist within the same geographical region (Letho and Haag, 2010). In freshwater rock pools on islands of the Baltic sea archipelago (Southern Finland), the asexual strains belong to the North American clade whereas the sexual strains belong to the European clade (Letho and Haag, 2010).

In Italy, the geographical distribution of $D$. pulex is broad but patchy, and probably over-estimated as the status of many populations is quite complicated by the existence of D. obtusa Kurz and D. curvirostris Eylmann, 1878 (Margaritora, 1985). D. pulex was recorded both in permanent and temporary habitats in Northern and Southern Italy (de Bernardi et al., 1985; Stoch et al., 2002; Marrone et al., 2007; Leoni and Garibaldi, 2009) and in several Italian islands: Sicily, Sardinia, Lampedusa and Capraia (Stoch et al., 2002; Marrone et al., 2006). By molecular markers, panarctic and North American D. pulex individuals were identified in Northern Italy and in Sardinia (Vergilino et al., 2011; Markova et al., 2013).

In April 2011, during a practice field trip, D. pulex was collected in a bodrio, located in the Cremona province in Northern Italy and in a nearby ephemeral pond. Bodrio is a word derived from the greek bothros which means hole, pit and it indicates a typical water body originated by erosion and evorsion from the old Po river-bed surface. In the Cremona province, at least 61 bodri have been listed. Major biodiversity and conservation studies on these habitats are based on vertebrates and plants (D'Auria and Zavagno, 1999). To our knowledge invertebrate freshwater groups need to be studied considering ponds as model systems in conservation ecology (De Meester et al., 2005).

The aim of the present paper was to report on the occurrence of D. pulex in the Bodrio del Pastore III and to describe its seasonal population dynamics and reproductive mode. This is a contribution to the knowledge of $D$. pulex in Europe.

\section{METHODS}

The Bodrio del pastore III ( $28 \mathrm{~m}$ asl, $45^{\circ} 00^{\prime} 05^{\prime \prime} \mathrm{N}$ $10^{\circ} 19^{\prime} 26^{\prime \prime} \mathrm{E}$, Hayford ellipsoid) formed presumably between 1723 and 1870 and is located in cultivated lands in Cremona province (AAVV, 1999). It has a surface area of about $3.130 \mathrm{~m}^{2}$, a perimeter of about $196 \mathrm{~m}$ and a maximum depth of $6.30 \mathrm{~m}$. It is considered a permanent water body and its volume is affected by River Po level, aquifer, precipitation, runoff and river inundations.

Periodical surveys were carried out from May 2011 to June 2013 and the bodrio was more intensively sampled in spring and early summer (Fig. 1). Zooplankton was collected by $105 \mu \mathrm{m}$-mesh net. From 2 to 161 of water were filtered for each sample according to the water volume and depth. Each sample was preserved in $90 \%$ ethanol. During each survey, water temperature was measured a few centimetres below the surface and maximum depth was recorded. The water volume was estimated by considering the bodrio conical shape according to the formula: $V=(S * h) / 3$ where $S$ is the surface area and $h$ is the maximum depth. Meteorological data about daily air temperature and rainfall were from the weather station LaCrosse WS2350 of Gussola.

Most cladocerans were identified to species level according to Margaritora (1985). Abundance of Daphnia was enumerated using $100 \%$ of each sample and the number of juveniles, adult males, adult females, ovigerous females and ephippial females was recorded. Body size (body length, from apex of head to the base of the tail spine) and spine length of at least 50 Daphnia females per samples were observed and measured using a stereomicroscope Nikon SMZ 2T and the Nis-Elements D 3.1 software (NIKON NIS Elements Imaging Software).

Regression analyses, Shapiro-Wilk test for normality distribution, Mann-Whitney and median non parametric tests were performed using SPSS 21.0 software.

\section{RESULTS}

Sampling was prevented by ice-cover in February and December 2012 and by adverse weather in the period January-March 2013. During the study, depth varied between 0.80 and $6.10 \mathrm{~m}$ with a mean value of $2.20 \mathrm{~m}$ (SD 1.58). Accordingly, the bodrio did not dry up. Its volume varied between $200 \mathrm{~m}^{3}$ (from August to November 2012) and $4321 \mathrm{~m}^{3}$ (June 5 2013). In spring 2013, both abundant rainfall and Po flood (May 21 $1^{\text {st }}, 2012$ ), accounted for its maximum volume. Water temperature recorded on sampling date was related to the mean air temperature recorded during 15 days before sampling date $\left(R^{2}=0.793\right.$;

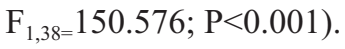

In the zooplankton assemblage 6 taxa of Cladocera were recorded: Alona sp., Ceriodaphnia dubia, Chydorus sphaericus, D. pulex, Moina micrura, Picripleuroxus denticulatus, Schapholeberis kingi and Simocephalus vetulus. Most of these species had their maximum development in spring. Only the small species $S$. kingi showed a slight presence in all seasons but winter time. M. micrura was recorded only in June 2011. D. pulex, as well as $S$. vetulus, showed an increase in density from spring to early sum- 
mer, declined in July-August and did not recover until successive spring. Chaoborus flavicans larvae were found: their density was high and almost constant in 2011 with the exception of the warmest months July and August and decreased significantly in the second half of 2012 and 2013 when only few individuals were recorded only in 3 samples (October 6 2012, April 242013 and June 5 2013). Quantitative data on Chaoborus density are not available.

In all the years the study was carried out, the $D$. pulex population was re-established in spring, probably from resting eggs (Fig. 2). The summer samples showed an increase in density and peaks were recorded just before a sharp population decrease in June-August, according to the year. In autumn and winter no Daphnia was recorded, but only very few juveniles in November 2011. Total density fluctuations were related to water temperature: population density increased during June-July accordingly and peaked at temperature between 15 and $20{ }^{\circ} \mathrm{C}$. Maximum density was observed on June $5^{\text {th }} 2013$ but population disappeared on June $18^{\text {th }} 2013$ when water temperature increased up to $29^{\circ} \mathrm{C}$ (Fig. 2). As expected, total density was related to juveniles density $\left(\mathrm{R}^{2}=0.921\right.$; $\left.\mathrm{F}_{1,31}=375.32 ; \mathrm{P}<0.001\right)$ that increased in summer due to the parthenogenetic reproduction phase (Fig. 2). Throughout the three year sampling period, juveniles of both gen- der, adult males, ephippial females and free ephippia were recorded throughout all the sampling period indicating that the sexual phase of cyclical parthenogenesis anticipates the population density peak (Fig. 3). Seasonal variation was observed in the frequency of individuals, most juveniles, showing a neckteeth, small spines on the dorsal part of the carapace that are adaptive predator-avoidance morphological traits (Fig. 4). In general, body size distributions of individuals with neckteeth (NT) and neckteethless ones (NL), were not normal and they were significantly different among years (Mann-Whitney $\mathrm{P}<0.001$ ) (Fig. 5). In 2011, most Daphnia juveniles of both gender showed a neckteeth through June and July months. Accordingly, NT females $(n=167$, mean $899.8 \pm 9.71 \mu \mathrm{m}$, median $=874.7 \mu \mathrm{m}$ ) were significantly smaller than NL adult females $(n=57$, mean $1057.4 \pm 41.25$ $\mu \mathrm{m}$, median $=947.21 \mu \mathrm{m})($ median test, $\mathrm{P}=0.014)$. In 2012, most juveniles were NL: body size of NT females $(n=45$, mean $892.1 \pm 23.14 \mu \mathrm{m}$, median $=879.94 \mu \mathrm{m})$ was significantly smaller than that of NL females $(n=193$, mean $1048.1 \pm 28.87 \mu \mathrm{m}$, median=958.93 $\mu \mathrm{m}$ ) (median test, $\mathrm{P}=0.047$ ). In 2013, all measured individuals of ex-ephippial generation and through May were NL $(n=304$, mean $971.75 \pm 13.36 \mu \mathrm{m}$, median=896.53 $\mu \mathrm{m})$ (Fig. 5). On June $5^{\text {th }}$ most individuals showed a neckteeth and their body

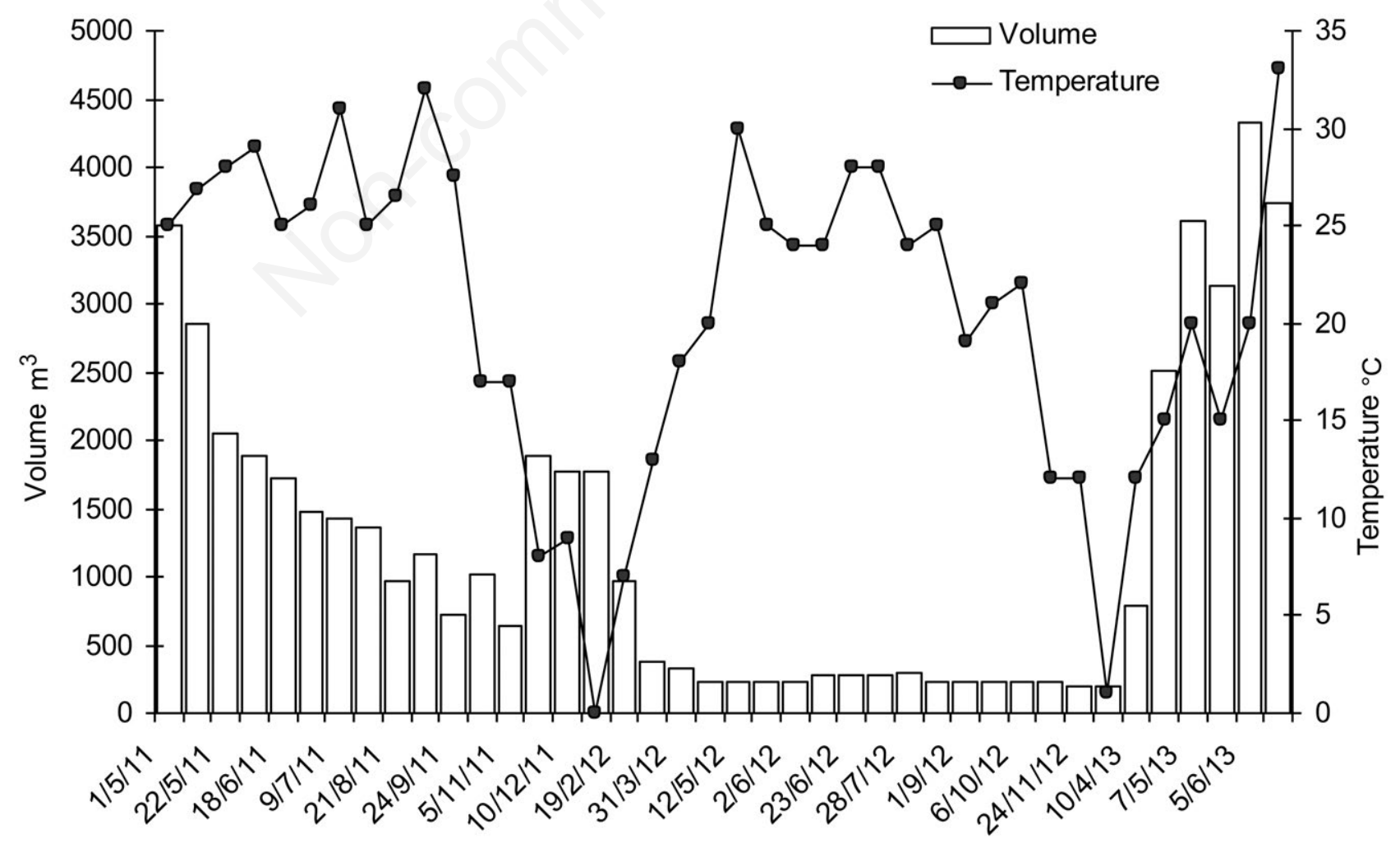

Fig. 1. Seasonal variation of water volume at sampling date and mean of air temperatures recorded during a 15 day period before sampling. 
size distribution was normal $(\mathrm{n}=84$, mean $1042.15 \pm 9.94$ $\mu \mathrm{m}$, median $=1051.24 \mu \mathrm{m}$ ); NL individuals were significantly larger $(\mathrm{n}=20$, mean $1196.53 \pm 54.64 \mu \mathrm{m}$, median $=1147.28 \mu \mathrm{m}$ ) than NT ones (median test, $\mathrm{P}=0.006$ ). In general, NT juveniles were smaller (median test, $\mathrm{P}<0.001$ ) and showed smaller body-tail spine ratio (median test, $\mathrm{P}<0.001)$ than $\mathrm{NL}$ ones. Total length, that is body plus spine size, varied significantly among years in juveniles (median test, $\mathrm{P}<0.001$ ) but not in adults (median test, $\mathrm{P}<0.054)$. Adult total length ranged from 1181 to $2565 \mu \mathrm{m}$.

\section{DISCUSSION}

Daphnia pulex was present in the Bodrio del pastore III only during spring and early summer, it declined and disappeared in late summer and recruited, the following spring, presumably by hatching of resting eggs. Thermal regime and the presence of the predaceous larvae of Chaoborus flavicans might account for the observed population dynamics and cyclomorphosis. The presence of active high density population was recorded when temperature was between 15 and $22^{\circ} \mathrm{C}$, a tolerance range that is in accordance with general reports on D. pulex (Margaritora, 1985; Havel, 1985; Black and Dodson, 1990) and with data from the Italian population of Lago Grande di Monticchio that was described by Leoni and Garibaldi (2009). The presence of C. flavicans might account for high juvenile mortality reducing the chance of parthenogenetic females to reach maturity. The highest population density observed in late spring 2013 was probably related both to lower mean temperature and lower predator density than in 2011 and 2012. However these were not the only factors affecting $D$. pulex population dynamics. In fact, in autumn, when temperature could be optimal, the species was not recorded with the single exception of 4 juveniles in November 2011. Assuming that the population recruitment is from ephippia, it may be that, in autumn, due to the so called refractory phase, ephippial eggs simply do not hatch (Stross, 1987; Rossi et al., 1998; Clark et al., 2012). Although we cannot rule out the effect of other factors (e.g., food quantity and/or quality, temperature) and we have no quantitative data on C. flavicans density, Chaoborus predation may account for seasonal variation of juveniles morphology. It is well known that, in presence of Chaoborus larvae, D. pulex developed neckteeths and/or elongated tail spines, especially in juvenile individuals, as inducible defences that increase the resistance to invertebrate predation (Havel, 1985; Col-

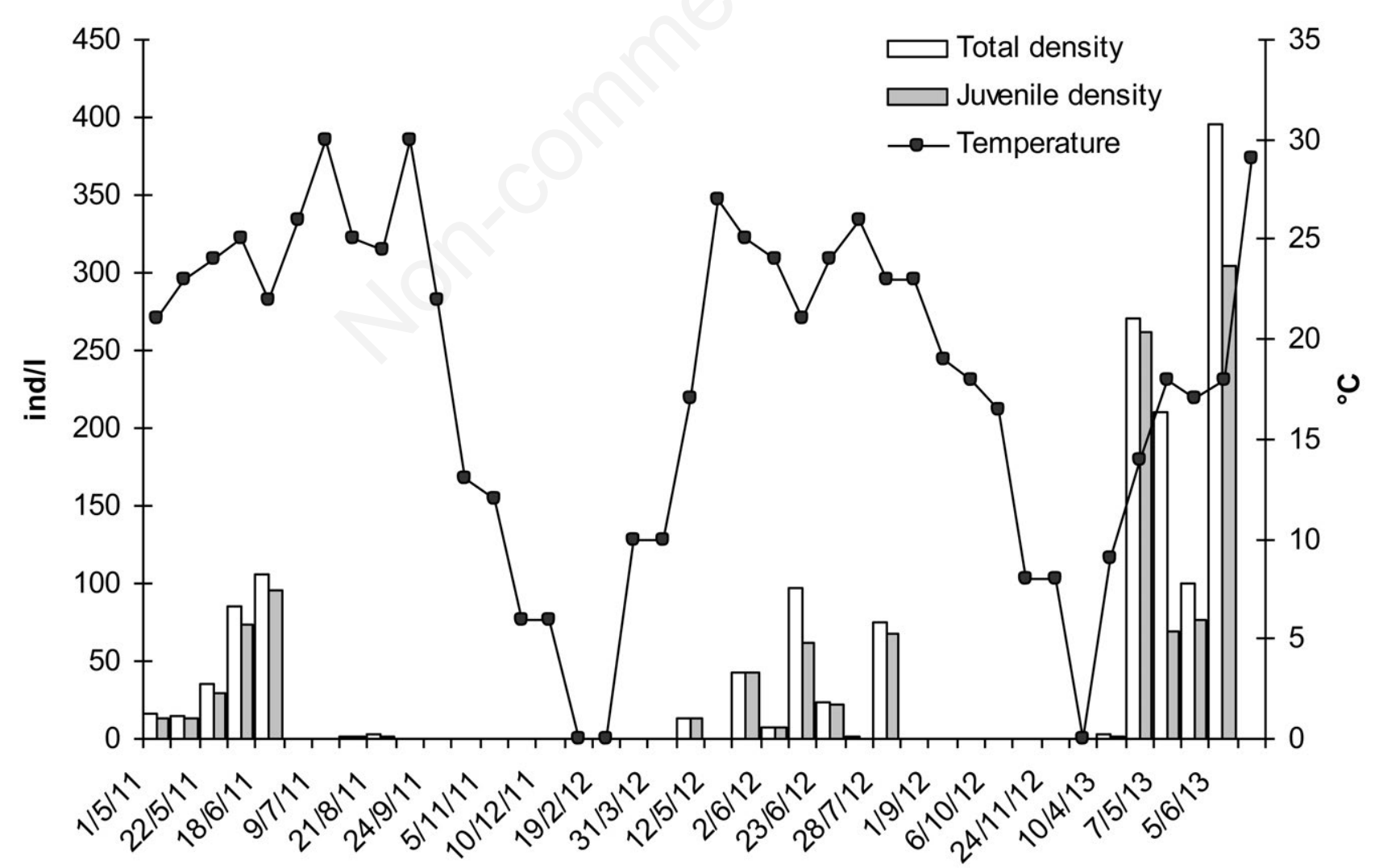

Fig. 2. Seasonal variation of water temperature, total density and juvenile density in $D$. pulex population. 
bourne et al. 1997; Kotov et al., 2006; Spanier et al., 2010; Herzog and Laforsch, 2013). According to Havel (1985), the proportion of juveniles which bears neckteeths is a positive function of both temperature (near or above $10^{\circ} \mathrm{C}$ ) and predator density (near or above $1 \mathrm{~L}^{-1}$ ). Our report is interesting because this phenomenon appears more common in North American than in European populations (Havel and Dodson, 1984; Hrbacek, 1987; Repka et al., 1995; Juracka et al., 2011).

The question is whether cyclomorphosis occurs via phenotypic plasticity of one or few clonal lineages that produce different phenotypes under different environmental conditions (e.g., kairomone dose and/or temperature). Alternatively, it should be due to clonal succession when the relative frequency of genotypes with different ability to develop a neckteeth changes during the season as a result of positive or negative selection by Chaoborus (or other environmental factors). According to Spitze (1991), Chaoborus predation removed $93-99 \%$ of initial genetic variability in 8-12 generations of clonal reproduction in
D. pulex inhabiting temporary ponds. Within populations, not all genotypes are likely to respond in the same way to predator stresses and strong interclonal variability is well known (Parejko and Dodson, 1991; Weber and Declerck, 1997), including opposite reactions within one species (Spitze, 1992; Boersma et al., 1998; Pauwels et al., 2005). There is indication that the production of neckteeths must occur during embryonic development, involve substantial strengthening of the carapace, may have demographic costs and may be poorly adaptive in other ways (Weber and Declerck, 1997; Wiebke et al., 2005; Juracka et al., 2011). The production of neckteeths appears to reduce the amount of resources for eggs and females exposed to Chaoborus kairomones usually tend to mature later, at larger size, and to produce fewer but larger newborn (Luning, 1992; Spitze, 1991; Riessen, 1992; Spitze, 1992; Tollrian, 1995; Weber and Declerck, 1997; Agrawal et al., 1999; Riessen, 1999; Boeing, 2006). Demographic costs linked to the production of neckteeths might further explain the density peak observed in the Bodrio del pastore

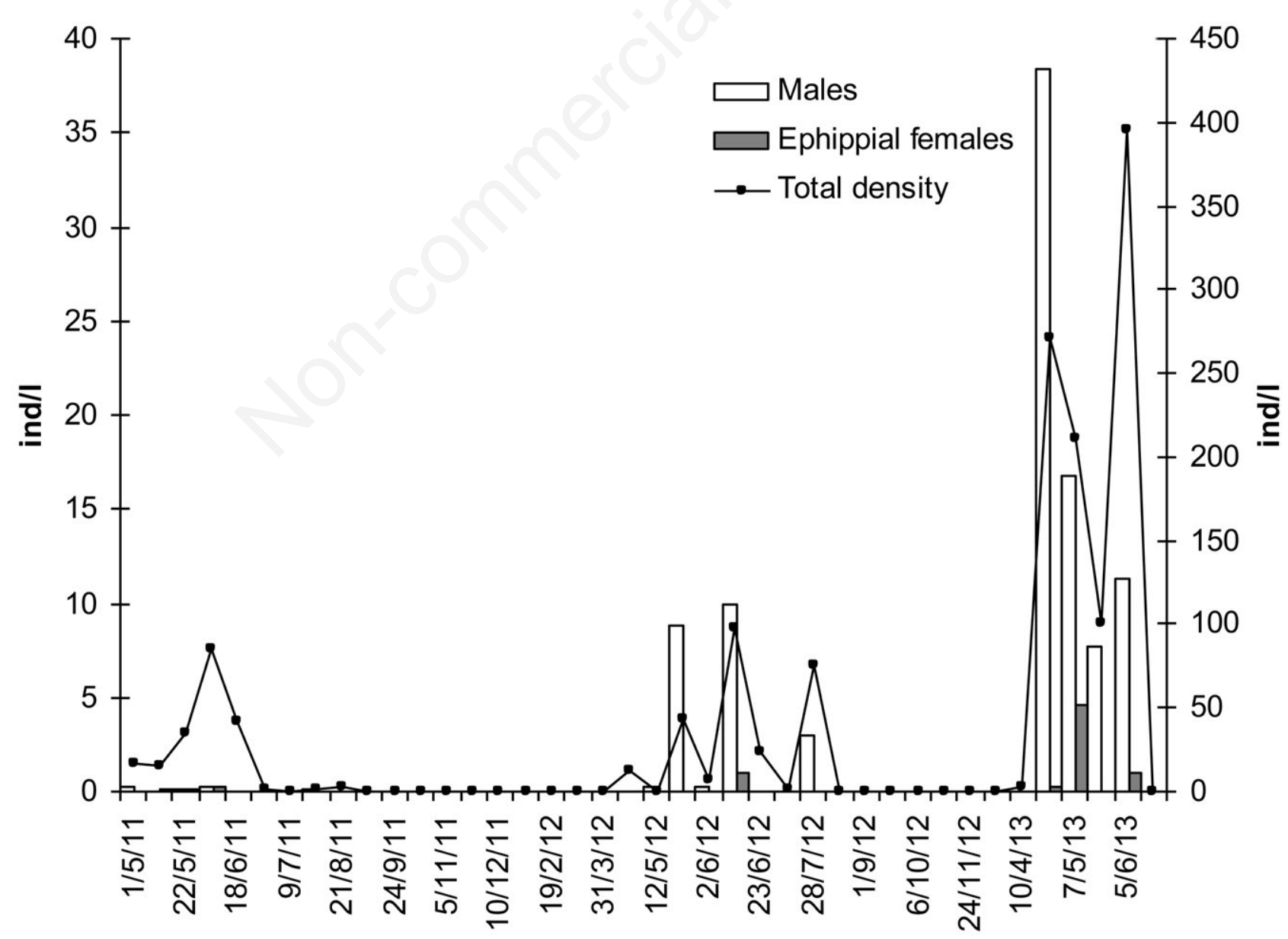

Fig. 3. Seasonal variation of total density, males, and ephippial females density in D. pulex population. 
III population in spring 2013, when most individuals were neckteeth-less. Long tail spine may be a low cost and good start-up defence when predation pressure may change rapidly (Havel, 1985; Tollrian, 1993). The size range we observed in total length of adult females was larger than that described in D. pulex from Southern Italy $(1310-2120 \mu \mathrm{m})($ Leoni and Garibaldi, 2009).

As expected in populations from temperate zones, $D$. pulex from the Bodrio del pastore III reproduce by cyclical parthenogenesis. In most Cladocera, sexual phase and male production begin after several generations of parthenogenetic reproduction with the production of subitaneously developing eggs. Switch to sexual reproduction and resting egg production is generally cued by a number of factors that are indicative of environmental deterioration (i.e., crowding and short-day photoperiod) and by maternal environmental conditions (Stross, 1987; Hobaek and Larsson, 1990; Innes and Dunbrack, 1993; Innes, 1997; LaMontagne and McCauley, 2001; Koch et al., 2009). In the bodrio, a very early investment in sexual reproduction, independent of population density, was observed. A similar feature was described in D. pulex from two temporary ponds in Ontario and suggested a lower influence of the environmental factors on sex determination compared to populations inhabiting more permanent habitats (Innes, 1997). Since sexual reproduction is required to produce resting eggs, the ability to lay them quickly and/or continually is adaptive in an small water body whose hydroperiod is unpredictable and uncertain. During our study period, the Bodrio del pastore III permanently hold water but we cannot rule out that periodi- cally it might dry out. Resting eggs are the primary dispersal stage and allow both colonisation of new sites and the persistence from year to year. Ephippial egg bank is expected to function as a reservoir of genetic diversity that may buffer populations against changes in the genotypic composition of the active population that may result from predator selection or disturbances (Spitze, 1991; Hairston, 1996). Annual recruitment of $D$. pulex from recombinant ephippial eggs guarantees the maintenance of genetic diversity and clonal variability. Lineages that produce males and ephippial females early in the season may escape from selection pressure by predators a meaningful percentage of genetic variation linked to sexual reproduction, so that evolution proceed toward earlier and increased sex allocation (Ruvinsky et al., 1986; Larsson, 1991; Innes and Dunbrack, 1993). A large genetic component and local adaptation (genetic control and genotype-environment interaction) might account for the feature of cyclical parthenogenesis of D. pulex from Bodrio del pastore III.

\section{CONCLUSIONS}

Our results suggest that further investigation are advisable in order to verify whether the current population is the last remnant of a once much larger metapopulation eventually reduced by anthropogenic disturbances (e.g., fish introductions, water contamination with toxic chemicals) or if it represents the invasion of North American strains that have recently colonised large parts of New Zealand, Africa and Spain, and that was already recorded in Northern Italy and Sardinia (Mergeay et al., 2006;
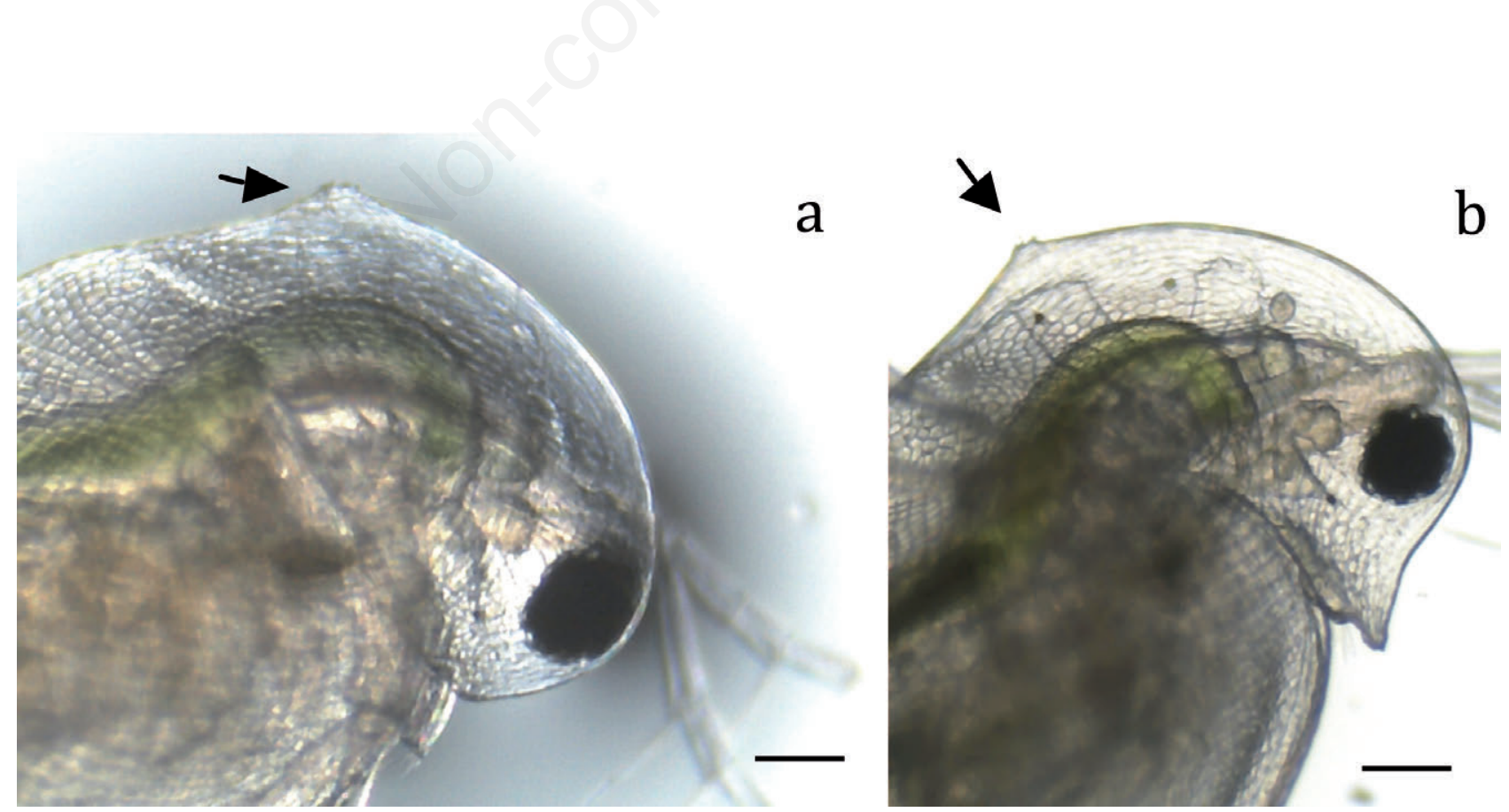

Fig. 4. Juveniles with neckteeth: a) male b) female. Arrows indicate the neckteeth. Scale bar: $60 \mu \mathrm{m}$. 


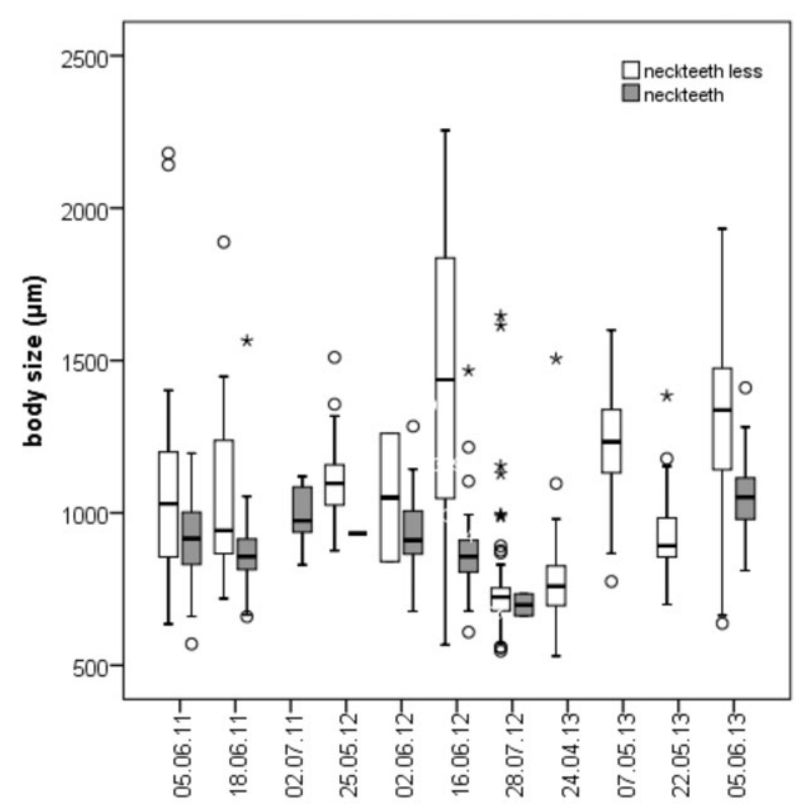

Fig. 5. Seasonal variation of body size in neckteethed and neckteeth-less females. Circles and asterisks indicate outlier data that are more than or less than 1.5-3 times (circle), or more than 3 times (asterisk) of upper or lower quartile.

Vergilino et al., 2011; Duggan et al., 2012; Crease et al., 2012; Markova et al., 2013).

\section{ACKNOWLEDGMENTS}

We wish to thank F. Margaritora for D. pulex identification and for her important suggestions, E. Cigarini for his assistance in Daphnia measurement, C. Cattabiani for manuscript revision and two anonymous referees for valuable comments on a previous version of the manuscript.

\section{REFERENCES}

AAVV, 1999. [Appunti sulla golena del Po. Le lanche di Motta Baluffi e Torricella del Pizzo].[Book in Italian]. Mus. Civ. St. Nat. Cremona Quad. 4.

Adamowicz SJ, Gregory TR, Marinone MC, Hebert PDN, 2002. New insights into the distribution of polyploidy Daphnia: the Holarctic and Argentina explored. Mol. Ecol. 11:1209-1217.

Agrawal AA, Laforsch C, Tollrian R, 1999. Transgenerational induction of defences in animals and plants. Nature 401:60-63.

Aguilera X, Mergeay J, Wollebrants A, Declerck S, De Meester L, 2007. Asexuality and polyploidy in Daphnia from the tropical Andes. Limnol. Oceanogr. 52:2079-2088.

Beaton MJ, Hebert PDN, 1988. Geographical parthenogenesis and polyploidy in Daphnia pulex. Am. Nat. 132:837-845.

Black AR, Dodson SI, 1990. Demographic costs of Chaoborusinduced phenotypic plasticity in Daphnia pulex. Oecologia 83:117-122.

Boeing WJ, 2006. Multiple predator defence strategies in Daph- nia pulex and their relation to native habitat. J. Plankton Res. 28:571-584.

Boersma M, Spaak P, De Meester L, 1998. Predator-mediated plasticity in morphology, life history, and behavior of Daphnia: the uncoupling of responses. Am. Nat. 152:237-248.

Clark MS, Denekamp NY, Thorne MAS, Reinhardt R, Drungowski M, Albrecht MW, Klages S, Beck A, Kube M, Lubzens E, 2012. Long-term survival of hydrated resting eggs from Brachionus plicatilis. PLoS ONE 7: e29365. doi:10.1371/journal.pone.0029365.

Colbourne JK, Hebert PDN, Taylor DJ, 1997. Evolutionary origins of phenotypic plasticity in Daphnia, p. 163-188. In: T.J. Givnish and K.J. Sytsma (eds.), Molecular evolution and adaptive radiation. Cambridge University Press.

Colburne JK, Crease TJ, Weider LJ, Hebert PDN, Dufresne F, Hobaek A, 1998. Phylogenetics and evolution of a circumarctic species complex (Cladocera: Daphnia pulex). Biol. J. Linn. Soc. 65:347-365.

Colbourne JK, Hebert PDN, 1996. The systematics of North American Daphnia (Crustacea: Anomopoda): a molecular phylogenetic approach. Philos. Trans. R. Soc. Lond. B 351:349-360.

Colbourne JK, Pfrender ME, Gilbert D, Thomas WK, Tucker A, Oakley TH, Tokishita S, Aerts A, Arnold GJ, Basu MK, Bauer DJ, Cáceres CE, Carmel L, Casola C, Choi JH, Detter JC, Dong Q, Dusheyko S, Eads BD, Fröhlich T, GeilerSamerotte KA, Gerlach D, Hatcher P, Jogdeo S, Krijgsveld J, Kriventseva EV, Kültz D, Laforsch C, Lindquist E, Lopez J, Manak JR, Muller J, Pangilinan J, Patwardhan RP, Pitluck S, Pritham EJ, Rechtsteiner A, Rho M, Rogozin IB, Sakarya O, Salamov A, Schaack S, Shapiro H, Shiga Y, Skalitzky C, Smith Z, Souvorov A, Sung W, Tang Z, Tsuchiya D, Tu H, Vos H, Wang M, Wolf YI, Yamagata H, Yamada T, Ye Y, Shaw JR, Andrews J, Crease TJ, Tang H, Lucas SM, Robertson HM, Bork P, Koonin EV, Zdobnov EM, Grigoriev IV, Lynch M, Boore JL, 2011. The ecoresponsive genome of Daphnia pulex. Science 331:555-561.

Crease TJ, Omilian AR, Costanzo KS, Taylor DJ, 2012. Transcontinental phylogeography of the Daphnia pulex species complex. PLoS One 7: e46620.

D’Auria G, Zavagno F, 1999. [Indagine sui “bodri” della Provincia di Cremona].[Book in Italian]. Monografie di Pianura n. 3. Provincia di Cremona Ed.: 230 pp.

De Bernardi R, Giussani G, Guilizzoni P, Mosello R, 1985. [Indagine conoscitiva per una caratterizzazione limnologica dei "piccoli laghi lombardi”].[Book in Italian]. Documenta Ist. Ital. Idrobiol: 205 pp.

De Meester L, Declerck S, Stoks R, Louette G, Van De Meutter F, De Bie T, Michels E, Brendonck L, 2005. Ponds and pools as model systems in conservation biology, ecology and evolutionary biology. Aquat. Conserv. 15:715-725.

Dufresne F, Hebert PDN, 1998. Temperature-related differences in life-history characteristics between diploid and polyploid clones of the Daphnia pulex complex. Ecoscience 5:433-437.

Duggan IC, Robinson KV, Burns CW, Banks JC, Hogg ID, 2012. Indentifying invertebrate invasion using morphological and molecular analyses: North America Daphnia "pulex" in New Zealand fresh waters. Aquatic Invasions 4:585-590.

Eads BD, Andrews J, Colbourne LK, 2008. Ecological genomics in Daphnia: stress responses and environmental sex determination. Heredity 100:184-190. 
Hairston NG, 1996. Zooplankton egg banks as biotic reservoirs in changing environments. Limnol. Oceanogr. 41:1087-1092.

Havel JE, Dodson SI, 1984. Chaoborus predation on typical and spined morphs of Daphnia pulex: behavioral observations. Limnol. Oceanogr. 29:487-494.

Havel JE, 1985. Cyclomorphosis of Daphnia pulex spined morphs. Limnol. Oceanogr. 30:853-861.

Hebert PDN, Finston TL, 2001. Macrogeographic patterns of breeding system diversity in the Daphnia pulex group from United States and Mexico. Heredity 87:153-161.

Herzog Q, Laforsch C, 2013. Modality matters for the expression of inducible defences: introducing a concept of predator modality. BMC Biology 11:113.

Hobaek A, Larsson P, 1990. Sex determination in Daphnia magna. Ecology 71:2255-2268.

Hrbacek J, 1987. Systematics and biogeography of Daphnia species in the Northern temperate regions. In: R.H. Peters and de Bernardi R. (eds.), Daphnia. Mem Ist. Ital. Idrobiol. 45:37-76.

Innes DJ, 1997. Sexual reproduction of Daphnia pulex in a temporary habitat. Oecologia 111:53-60.

Innes DJ, Dunbrack RL, 1993. Sex allocation variation in Daphnia pulex. J. Evol. Biol. 6:559-575.

Innes DJ, Hebert PDN, 1988. The origin and genetic basis of obligate parthenogenesis in Daphnia pulex. Evolution 42:1024-1035.

Jose C, Dufresne F, 2009. Differential survival among genotypes of Daphnia pulex differing in reproductive mode, ploidy level, and geographic origin. Evol. Ecol. 24:413-421.

Juracka PJ, Laforsch C, Petrusek A, 2011. Neckteeth formation in two species of the Daphnia curvirostris complex (Crustacea: Cladocera). In J. Seda and A. Petrusek (eds.) Daphnia as a model organism in limnology and aquatic biology: some aspects of its reproduction and development. J. Limnol. 70:359-368.

Kerfoot CW, 1980. Evolution and ecology of zooplankton communities. University Press of New England: 793 pp.

Koch U, von Elert E, Straile D, 2009. Food quality triggers the reproductive mode in the cyclical parthenogen Daphnia (Cladocera). Oecologia 159:317-24.

Kotov AA, Ishida S, Taylor DJ, 2006. A new species in the Daphnia curvirostris (Crustacea: Cladocera) complex from the eastern Palearctic with molecular phylogenetic evidence for the independent origin of neckteeth. J. Plankton Res. 28:1067-1079.

La Montagne JM, McCauley E, 2001. Maternal effects in Daphnia: what mothers are telling their offspring and do they listen? Ecol. Lett. 4:64-71.

Larsson P, 1991. Intraspecific variability in response to stimuli for male and ephippia formation in Daphnia pulex. Hydrobiologia 225:281-290.

Lehto MP, Haag CR, 2010. Ecological differentiation between coexisting sexual and asexual strains of Daphnia pulex. J. Anim. Ecol. 79:1241-1250.

Leoni B, Garibaldi L, 2009. Population dynamics of Chaoborus flavicans and Daphnia spp.: effects on a zooplankton community in a volcanic eutrophic lake with naturally high metal concentrations (L. Monticchio Grande, Southern Italy). J. Limnol. 68:37-45.

Luning J, 1992. Phenotypic plasticity of Daphnia pulex in the presence of invertebrate predators: morphological and life history responses. Oecologia 92:383-390.

Margaritora GF, 1985. Cladocera. Fauna d'Italia, Calderini, Bologna: 399 pp.

Markova S, Dufresne F, Manca M, Kotlík P, 2013. Mitochondrial capture misleads about ecological speciation in the Daphnia pulex complex. PLoS One 8:e69497.

Marrone F, Alfonso G, Naselli-Flores L, 2007. On Daphnia (Ctenodaphnia) similis Claus, 1876 and other interesting anomopods (Crustacea, Branchiopoda) from Apulia (Southern Italy). Thalassia Salentina 30:45-55.

Marrone F, Barone R, Naselli-Flores L, 2006. Cladocera (Branchiopoda: Anomopoda, Ctenopoda, and Onychopoda) from Sicilian inland waters: an updated inventory. Crustaceana 78:1025-1039.

Mergeay J, Verschuren D, De Meester L, 2006. Invasion of an asexual American water flea clone throughout Africa and rapid displacement of a native sibling species. P. R. Soc. B 273:2839-2844.

Mergeay J, Ximena A, Declerck S, Petrusek A, Huyse T, De Meester L, 2008. The genetic legacy of polyploid Bolivian Daphnia: the tropical Andes as a source for both the North and South American D. pulicaria complex. Mol. Ecol. 17:1789-1800.

Palsoon S, 2000. Microsatellite variation in Daphnia pulex from both sides of the Baltic Sea. Mol. Ecol. 9:1075-1088.

Parejko K, Dodson SI, 1991. The evolutionary ecology of an antipredator reaction norm: Daphnia pulex and Chaoborus americanus. Evolution 45:1665-1674.

Pauwels K, Stoks R, De Meester L, 2005. Coping with predator stress: interclonal differences in induction of heat-shock proteins in the water flea Daphnia magna. J. Evol. Biol. 18:867-872.

Peters RH, de Bernardi R, 1987. Daphnia. Mem. Ist. Ital. Idrobiol. 45:1-502.

Petrusek A, Hobaek A, Nilssen JP, Skage M, Cerny M, Brede N, Schwenk K, 2008. A taxonomic reappraisal of the European Daphnia longispina complex (Crustacea, Cladocera, Anomopoda). Zool. Scr. 37:507-519.

Repka S, Walls M, Ketola M, 1995. Neck spine protects Daphnia pulex from predation by Chaoborus, but individuals with longer tail spine are at a greater risk. J. Plankton Res. 17:393-403.

Riessen HP, 1992. Cost and benefit model for the induction of an antipredator defence. Am. Nat. 140:349-362.

Riessen HP, 1999. Predator-induced life history shifts in Daphnia: a synthesis of studies using meta-analysis. Can. J. Fish. Aquat. Sci. 56:2487-2494.

Rossi V, Rossetti G, Benatti M, Menozzi P, Ferrari I, 1998. Ephippial eggs and dynamics of the clonal structure of Daphnia longispina (Crustacea: Cladocera) in a mountain lake (Lago Scuro Parmense, Northern Italy). Arch. Hydrobiol. Spec. Issues Advanc. Limnol. 52:195-206.

Ruvinsky AO, Perelygin AA, Lobkov YL, Belyaev DK, 1986. Factors organising and maintaining polymorphism in a cyclic parthenogenetic species: Daphnia pulex. Heredity 57:15-22.

Schaack S, 2008. Daphnia comes of age: an ecological model in the genomic era. Mol. Ecol. 17:1634-1635.

Seda J, Petrusek A, 2011. Daphnia as a model organism in lim- 
nology and aquatic biology: some aspects of its reproduction and development. J. Limnol. 70:359-368.

Spanier K, Leese F, Mayer C, Colbourne JK, Gilbert D, Pfrender ME, Tollrian R, 2010. Predator-induced defences in Daphnia pulex: Selection and evaluation of internal reference genes for gene expression studies with real-time PCR. BMC Mol. Biol. 11:50.

Spitze K, 1991. Chaoborus predation and life-history evolution in Daphnia pulex: temporal pattern of population diversity, fitness, and mean life history. Evolution 45:82-92.

Spitze K, 1992. Predator-mediated plasticity of prey life history and morphology: Chaoborus americanus predation on Daphnia pulex. Am. Nat. 139:229-247.

Stoch F, Latella L, Lapini L, 2002. Taxonomy: p. 87-127. Caves and karsic phenomena. Quaderni Habitat, Min. Amb. Mus. Friul. St. Nat. Udine.

Stross RG, 1987. Photoperiodism and phased growth in Daphnia population: coactions in perspective. In R.H. Peters and de Bernardi R. (eds), Daphnia. Mem Ist. Ital. Idrobiol. 45:413-437.

Tessier AJ, Bizina EV, Geedey CK, 2001. Grazer-resource interactions in the plankton: Are all daphniids alike? Limnol. Oceanogr. 46:1585-1595.

Tollrian R, 1993. Neckteeth formation in Daphnia pulex as an example of continuous phenotypic plasticity - morphological effects of Chaoborus kairomone concentration and their quantification. J. Plankton Res. 15:1309-1318.

Tollrian R, 1995. Predator-induced morphological defences: costs, life history shifts, and maternal effects in Daphnia pulex. Ecology 76:1691-1705.
Vergilino R, Markova S, Ventura M, Manca M, Dufresne F, 2011. Reticulate evolution of the Daphnia pulex complex as revealed by nuclear markers. Mol. Ecol. 20:1191-1207.

Ward RD, Bickerton MA, Finston TL, Hebert PDN, 1994. Geographical cline in breeding system and ploidy levels in European populations of Daphnia pulex. Heredity 73: 532-543.

Weber A, Declerck S, 1997. Phenotypic plasticity of Daphnia life history traits in response to predator kairomones: genetic variability and evolutionary potential. Hydrobiologia 360:89-99.

Weider LJ, Hebert PDN, 1987. Ecological and physiological differentiation among low-arctic clones of Daphnia pulex. Ecology 68:188-198.

Weider LJ, Hobaek A, 1997. Postglacial dispersal, glacial refugia, and clonal structure in Russian/Siberian populations of the arctic Daphnia pulex complex. Heredity 78:363-372.

Weider LJ, Hobaek A, 2003. Glacial refugia, haplotype distributions, and clonal richness of the Daphnia pulex complex in arctic Canada. Mol. Ecol. 12:463-473.

Weider LJ, Hobaek A, Colbourne JK, Crease TJ, Dufresne F, Hebert PDN, 1999. Holarctic phylogeography of an asexual species complex. I. Mitochondrial DNA variation in arctic Daphnia. Evolution 53:777-792.

Weider LJ, Pijanowska J, 1993. Plasticity of Daphnia pulex life histories to chemical cues from predators. Oikos 67:385-392.

Wiebke J, Boeing B, Wissel C, Ramcharan W, 2005. Costs and benefits of Daphnia pulex defence against Chaoborus in nature. Can. J. Fish. Aquat. Sci. 62:1286-1294. 